\title{
Analisis Faktor-Faktor yang Melatarbelakangi Preferensi Menabung Santri di Tabungan Santri Mandiri, Pondok Pesantren Raudlatul Ulum 1, Ganjaran, Gondanglegi, Malang.
}

\section{Syifaur Romli \& Zainudin Fanani}

\author{
Program Studi Hukum Ekonomi Syariah, Fakultas Syariah, \\ Institut Agama Islam Al-Qolam \\ Email: romlifj@gmail.com, \\ zainuddinfanani82@gmail.com
}

\begin{abstract}
This study aims to conduct an analysis related to the analysis of factors that influence students' interest in saving at the Tabungan Santri Mandiri in the Islamic Boarding School of Raudlatul Ulum 1 Ganjaran Gondanglegi Malang. This research is qualitative using the documentation and an interview in method of data collection. The conclusion of this research is that the factors underlying the saving preferences of students are positive factors which are things that can be a stimulus for their interests and motivation to carry out the obligation to save. These factors include: the existence of remaining allowance, future investment, an adherence to regulations to the influence of the surrounding environment. Second, things that can
\end{abstract}

150 Vol. 4, No. 2, September 2019 
be an obstacle to their interest and motivation to be reluctant to carry out the obligation to save include the lack of socialization, poor service, economic limitations and others.

Keywords: Saving, Economics Education, Motivation, Islamic Saving.

\section{Pendahuluan}

Seiring dengan perkembangan zaman, timbul pula di dalamnya suatu persoalan baru dalam dunia usaha (bisnis) serta ekonomi dan keuangan yang belum pernah dikenal oleh orang terdahulu bahkan yang hampir mendekati masanya. ${ }^{1}$ Menurut Meyers, ilmu ekonomi mendefinisikan arti etimologinya sebagai ilmu yang mempersoalkan kebutuhan dan kepuasan hidup manusia. ${ }^{2}$

Seiring dengan semakin mengakarnya kebutuhan sesorang dalam ketergantungannya terhadap materi, maka menyisihkan serta kemudian menyimpan sebagian materinya menjadi sebuah solusi demi stabilitas keseimbangan materinya di waktu mendatang. Cara demikian ini kemudian dikenal dengan istilah "Menabung". Dalam

\footnotetext{
${ }^{1}$ Muhamad, Manajemen Kenangan Syari'ah, Cet. II (Yogyakarta: UPP STIM YKPN, 2016), 17. 18.

2 Siti Nur Fatoni, Pengantar Ilmu Ekonomi, Cet. I (Bandung: Pustaka Setia, 2014),
} 
Undang-Undang Perbankan dijelaskan bahwa "Tabungan adalah simpanan yang penarikannya hanya dapat dilakukan menurut syarat tertentu yang disepakati, tetapi tidak dapat ditarik dengan cek, bilyet giro dan atau alat lainnya yang dipersamakan dengan itu". ${ }^{3}$ Dari definisi hukum di atas, barang tentu mencakup segala bentuk materi fisik yang bisa ditabungkan. Walaupun hingga saat ini, kata menabung telah menjadi mindset mayoritas orang bahwa bentuk materi yang umum ditabungkan hanya dimuarakan kepada uang saja.

Dalam dunia pendidikan pesantren, aktifitas menabung juga turut dilakukan oleh kaum santri. Ketergantungan dirinya sebagai mahluk sosial terhadap materi juga menjadi indikator bahwa kebutuhannya di masa mendatang juga tak lepas dari perhatian. Guna menunjang kebutuhan kompleks yang lain demi optimalnya aktivitas yang eksistensinya bergantung terhadap ketersediaan materi itu sendiri. Termasuk antisipasinya melalui metode menabung. Sekalipun ketersediaan uang sebagai benda materi yang dimiliki para santri mayoritas masih bergantung terhadap peras keringat orang tua di satu sisi, juga sebenarnya cukup apabila disisihkan sebagiannya guna disimpan demi pemenuhan kebutuhan di masa mendatang di lain sisi.

\footnotetext{
${ }^{3}$ Undang-Undang Republik Indonesia Nomor 10 Tahun 1998 Tentang Perbankan.
}

152 Vol. 4, No. 2, September 2019 
Ajaran untuk senantiasa berperilaku berhemat dalam melakukan distribusi materi sebenarnya telah diajarkan secara turun temurun dari generasi ke generasi keilmuan kepesantrenan. Baik secara teoritis, maupun praktis. Selain berorientasi serta berdasar dari ayat Al-Qur'an sebagaimana yang salah satunya telah dipaparkan di atas, juga suri tauladan dari jejak mulya nabi Muhammad SAW sebagaimana dijelaskan dalam suatu hadits,

Dari Umar berkata: "Harta benda milik bani Nadhir yang diberikan kepada Rasulullab SAW. Tidak ada kewenangan bagi kaum muslimin. Hanya khusus diperuntukkan pada nabi. Nabi menggunakan barta itu (menyimpan) guna menafkabi keluarganya selama setahun, kemudian sisanya diberikan untuk. keperluan perang di jalan Allah SWT (HR. Buhkari)”.

Santri, sebagai identitas penduduk pesantren juga tak lepas dari peranan realita sosial. Sebagai pemeluk, penjaga, pengembang serta pelestari kultur agama Islam, maka peranannya terhadap perkembangan ekonomi dan demokrasi juga benar-benar berpengaruh ${ }^{4}$ Sebagai bentuk upaya islamisasi ekonomi

${ }^{4}$ Fatih Syuhud, Santri, Pesantren dan Tantangan Pendidikan Islam, Cet. II (Karangsuko: Pustaka ALKHOIROT, 2008), 57.

Iqtishodia : Jurnal Ekonomi Syariah 
konvensional, maka peranan pesantren dalam membentuk karakter peduli terhadap ekonomipun juga perlu memiliki respon lebih dengan melakukan beberapa metode sebagaimana dijelaskan Monzer Kahf. Pertama, elaborasi sistem ekonomi islam. Kedua, melakukan revisi terhadap sistem perekonomian konvensional. ${ }^{5}$ Sebagaimana yang telah diupayakan dalam dunia pesantren termasuk dalam bidang terkecilnya adalah menabung.

Pondok Pesantren Raudlatul Ulum 1 Ganjaran, Gondanglegi, Malang adalah termasuk salah satunya. Pondok pesantren ini bernisiatif mewujudkan mediator guna menfasilitasi kebutuhan santri dalam menabung. Kegiatan menabung santri di pesantren sendiri sebenarnya memiliki banyak manfaat. Selain membantu terhadap injeksi kapasitas ekonomi melalui pengelolaan sementara uang tabungan santri yang nantinya akan kembali terhadap pesantren mereka pribadi di satu sisi, juga akan membantu pemenuhan kebutuhan sekunder santri menghadapi liburan rutin tanpa harus membebani orang tua kembali, di sisi yang lain. Maka secara tidak langsung juga merupakan metode pendidikan karakter untuk terbiasa

\footnotetext{
${ }^{5}$ Rahmad Hakim, "Islamisasi Ekonomi Mad₹̧hab Mainstream: Tinjauan, Model dan Implikasi”, Iqtishodia: Jurnal Ekonomi Syari'ah, Vol. 1, No.1, (Maret, 2016), 8182.
}

154 Vol. 4, No. 2, September 2019 
hemat dan hidup mandiri yang merupakan salah satu moto pesantren Raudlatul Ulum 1 Ganjaran Gondanglegi Malang.

Alternatif tersebut kemudian dibentuk dan dijadikan program wajib yang kemudian bernama "Tabungan Santri Mandiri”. Telah beroperasi sejak tahun 2014 dan tetap berjalan sampai saat ini. Dalam sistemnya, pesantren mewajibkan setiap santri untuk menabungkan uangnya minimal sebesar Rp. 2000,- perminggunya. Dan hanya boleh dicairkan dan diambil dalam jangka waktu satu tahun satu kali menjelang liburan di bulan Ramadan. Tentu dengan alasan kompleks dalam setiap kebijakan yang di ambil.

Dari awal beroperasinya sampai saat ini, bukan santri namanya jika dalam ilustrasi kehidupannya tak dilengkapi dengan dilema. Peraturan menjadi sebuah rambu nyata yang tetap saja berdampak dilanggar. Meski tidak seluruhnya, namun pelanggaran semacam itu dapat menimbulkan dampak terhadap akses peluang pengembangan kapasitas perekonomian pesantren, penghambat realisasi motto pesantren, pembengkakan angka tunggakan syahriah santri, mempengaruhi semangat menabung santri lainnya di satu sisi, juga menjadi sebuah benih kebiasaan melanggar bagi para santri di sisi yang lain. 
Penelitian ini bertujuan untuk melakukan analisis terkait analisis faktor-faktor yang mempengaruhi minat menabung santri Pada Tabungan Santri Mandiri di Pondok Pesantren Raudlatul Ulum 1 Ganjaran Gondanglegi Malang.

\section{Landasan Teori}

\subsection{Preferensi}

Preferensi adalah sebuah pilihan atau keadaan yang lebih disukai, pilihan atau kecenderungan; kesukaan. ${ }^{6}$ Preferensi berasal dari bahasa Inggri preference yang memiliki arti "a greater liking for one alternative over another or others" (kesukaan terhadap suatu hal dibanding dengan hal lainnya). Assael berpendapat bahwa "Preferensi" terbentuk dari persepsi konsumen (objek) terhadap produk (produk). Assael membatasi kata persepsi itu sendiri sebagai suatu perhatian kepada pesan yang mengarah kepada ingatan dan perhatian. Kemudian persepsi yang telah mengendap di fikiran seseorang akan menjadi preferensi. ${ }^{7}$

${ }^{6}$ Pius A Partanto, Kamus Ilmiah Populer (Surabaya: Arkola, 2001), 627.

7 "Preferensi Konsumen dan Tahapannya", ciputruceo.net (diakses pada 02 Mei 2016).

156 Vol. 4, No. 2, September 2019 
Teori preferensi sendiri bisa digunakan untuk menganalisa tingkat kepuasan konsumen (dalam hal ini adalah santri). Misal seseorang jika ingin menggunakan atau mengkonsumsi suatu hal berupa, produk dan atau jasa (dalam penelitian ini adalah program “Tabungan Santri Mandiri”) dengan sumber daya yang terbatas maka dia dihadapkan pada pilihan alternatif sehingga nilai guna atau utilitas yang didapatnya mencapai tingkat optimal. ${ }^{8}$ Jika direlevansikan dengan objek penelitian ini, maka preferensi memiliki kesimpulan ringan sebagai sebuah minat.

Preferensi atau minat adalah sebuah kecenderungan seseorang untuk melakukan atau menentukan aktivitas. Adapun minat dapat dipengaruhi oleh kondisi individual yang cenderung berubah-ubah (tidak stabil). Sedangkan menurut istilah minat adalah seperangkat mental yang terdiri dari campuran perasaan, harapan, prinsip, prasangka atau kecenderungan lain yang menyebabkan dapat mengarahkan individu kepada satu pilihan tertentu. ${ }^{9}$

Dengan demikian dapat dikatakan bahwa minat adalah dorongan yang kuat dari dalam diri seseorang untuk melakukan

\footnotetext{
${ }^{8}$ Muhammad Haris, "Analisis Faktor-Faktor yang Mempengaruhi Preferensi Nasabah Terhadap Bank Syariah di DKI Jakarta", Skripsi (Bogor: Institut Pertanian Bogor, 2015), 7.

${ }_{9}^{9}$ Andi Mappiare, Psikologi Remaja, (Surabaya: Usaha Nasional, 1997), 62.
}

Iqtishodia : Jurnal Ekonomi Syariah 
sesuatu yang diinginkan. Minat tersebut dapat timbul dari berbagai faktor yakni internal dan eksternal. Minat dapat menjadi dorongan seseorang dalam rangka mencapai cita-cita dan keinginannya. Minat yang besar terhadap suatu hal merupakan modal utama untuk membangkitkan semangat seseorang yang dalam hal ini adalah minat menabung.

Preferensi atau minat menabung di kalangan santri, jika dapat diterapkan dengan baik akan memiliki nilai positif baik bagi santri sendiri maupun bagi lembaga. Preferensi konsumen jelas berhubungan erat dengan permasalahan penetapan pilihan, sikap dasar yang digunakan untuk menerangkan pilihan menentukan tingkah laku individu dalam masalah penetapan pilihan.

\subsection{Definisi Tabungan dan Teori Menabung}

Tabungan adalah simpanan harta berbentuk uang yang hanya dapat dilakukan penarikan menurut standar dan syarat-syarat tertentu yang telah disepakati. ${ }^{\mathbf{1 0}}$ Sebagai contoh tabungan dalam sistem Perbankan, nasabah dapat melakukan penarikan atau jika nasabah berkehendak untuk mengambil simpananannya yaitu dengan cara

10 Abdul Ghofur Anshori, Perbankan Syariah di Indonesia, (Yogyakarta: Gadjah Mada University Press, 2009), 92.

158 Vol. 4, No. 2, September 2019 
datang langsung ke Bank dengan membawa buku tabungan, slip penarikan, copy kartu identitas (atau syarat lain sesuai ketentuan Bank) atau bisa melalui mesin ATM.

Lain halnya dengan sistem tabungan yang diterapkan pada Lembaga Keuangan Non-Bank, seperti di Sekolah, Pesantren, maupun yang diterapkan pada organisasi masyarakat tertentu. Pada umumnya, yang diterapkan pada Lembaga Keuangan Non-Bank dalam hal penarikannya adalah berjangka sebagaimana yang telah diatur dan disepakati bersama.

Tabungan adalah simpanan dana yang berdasarkan akad wadi'ah atau investasi dana berdasarkan akad mudharabah atau akad lain yang tidak bertentangan dengan prinsip syariah, dimana penarikannya hanya dapat dilakukan atas dasar syarat dan ketentuan yang telah disepakati. ${ }^{11}$

Menurut bahasa tabungan adalah wujud simpanan nasabah yang bersifat likuid, hal ini memberikan makna bahwa produk tabungan ini dapat diambil sewaktu-waktu jika nasabah menghendaki

\footnotetext{
11 Undang-Undang Nomor 21 Tahun 2008 Tentang Perbankan Syariah (Pasal 1).
}

Iqtishodia : Jurnal Ekonomi Syariah 
atau membutuhkan. Tetapi konsep tersebut hanya berlaku bagi nasabah penabung kecil. ${ }^{12}$

Tabungan jika dilaksanakan dengan prinsip yang sesuai syariat dan menjunjung tinggi kemashlahatan, maka akan mendatangkan kebaikan bagi pihak-pihak terkait. Namun juga tidak dapat dipungkiri bahwa tidak semua orang suka atau berminat terhadap tabungan. Banyak hal yang melatarbelakangi minat maupun motivasi manusia dalam menabung. Manusia yang sejatinya adalah makhluk yang selalu terkait dengan kegiatan konsumsi dan kemudian disebut dengan konsumen.

Dalam fatwanya Dewan Pengawas Syariah menetapkan untuk membagi tabungan menjadi dua jenis (Fatwa DSN No. 02 / DSNMUI / IV / 2000), yaitu sebagai berikut:

a. Tabungan dalam konsep konvensional

Yakni tabungan yang tidak dibenarkan dan tidak sesuai dengan prinsip Islam, yaitu tabungan yang dalam prakteknya menerapkan sistem bunga.

b. Tabungan dalam konsep Syariah

12 M. Nur Rianto Al Arif, Dasar-Dasar Ekonomi Islam, Cet. II (Bandung: Alfabeta, 2012), 327-328.

160 Vol. 4, No. 2, September 2019 
Yakni tabungan yang dibenarkan dan sesuai dengan prinsip Islam, yaitu tabungan yang dalam prakteknya menerapkan akad wadi'ah dan akad mudharabah. ${ }^{\mathbf{1 3}}$

Adanya pembagian tersebut, dikarenakan oleh tidak semuanya tabungan dibenarkan dan dianggap sah oleh hukum Islam. Dan oleh karenanya DSN menerangkan adanya penetapan mengenai bentuk-bentuk mu'amalah syari'ah untuk dijadikan pedoman bagi umat muslim dalam segala transaksinya, khususnya dalam bidang tabungan.

Dengan demikian, jika tabungan diselaraskan dengan prinsip Islami selayaknya bagi konsumen (manusia) lebih bijak dalam mengatur segala bentuk kegiatannya terlebih dalam aktivitas ekonomi. Karena sejak dahulu, kegiatan ekonomi adalah kegiatan yang paling sensitif sebab selalu berkaitan dengan harta, baik dalam bentuk uang maupun lainnya. Sehingga sebagai konsumen muslim harus mengerti arti penting dari berbagai transaksi yang dilakukan, tidak terkecuali dalam menabung.

Menabung merupakan kegiatan menyisihkan sebagian uang ataupun pendapatan dalam rangka mengelola uang tersebut. Dengan menabung, seseorang akan lebih berhemat dalam membelanjakan

${ }^{13}$ Ibid., 328. 
hartanya. Dan dengan demikian, ketika seseorang melakukan penghematan terhadap pola perilaku konsumtif maka pola perilaku simpanan akan mengalami peningkatan. Hal tersebut akan menjadi sangat penting demi terpenuhi dan tercukupinya kebutuhan jangka panjang. Semakin bertambah kebutuhan pengeluaran di masa kini, manusia juga harus semakin pandai dalam mengatur keuangannya.

\subsection{Motivasi Menabung}

Menabung berasal dari kata dasar tabung yang memiliki arti celengan atau tempat menyimpan uang. ${ }^{14}$ Sedangkan "Menabung" adalah suatu perilaku menyimpan uang baik secara pribadi maupun kepada orang lain atau penyedia jasa layanan penyimpanan uang seperti bank, koperasi dan lainnya baik BUMN maupun swasta.

Motivasi adalah sesuatu yang berawal dari perasaan tertekan menjadi sebuah kehendak. Kehendak ini termaktub dalam nalar manusia yang memberikan makna terhadap sesuatu apa saja yang ingin dicapai. ${ }^{15}$ Menurut Keynes, ada 8 motivasi konsumen yang berbeda dalam menabung yaitu:

${ }^{14}$ KBBI, Op.Cit.

15 C. George Boeree, Psikologi Sosial (Jogjakarta: Primashopie, 2014), 25.

162 Vol. 4, No. 2, September 2019 
a. Tindakan pencegahan, yang berimplikasi pada menambah cadangan untuk menghadapi keadaan yang tidak terduga;

b. Tujuan masa depan, untuk mengantisipasi perbedaan antara pendapatan dan pegeluaran belanja di masa depan;

c. Perhitungan, ingin memperoleh keuntungan/bunga;

d. Perbaikan, meningkatkan standar hidup dalam waktu yang lama;

e. Kebebasan, menunjukkan adanya kebutuhan akan kebebasan dan memiliki kekuasaan untuk melakukan sesuatu;

f. Usaha, adanya kebebasan untuk menanamkan uang ketika memungkinkan;

g. Kebanggaan, lebih tertuju pada penempatan uang untuk ahli waris dan;

h. Keserakahan harta atau kekikiran yang sesungguhnya. ${ }^{\mathbf{1 6}}$ Sedangkan dalam Islam, motivasi disebut juga dengan niat. Maksudnya motivasi atau niat ini adalah sesuatu yang terkadung dalam hati seseorang yang berindikasi pada perbuatan atau melakukan

\footnotetext{
16 Wahyu Utami, et.al., "Analisis Pengaruh Religiuitas, Kelompok Referensi, dan Motivasi Terhadap Keputusan Menabung di Bank Syariah", Jurnal Wawasan Manajemen, Vol. 3, 1 (Februari, 2015), 82.
} 
sesuatu. Motivasi atau niat adalah kriteria utama sebagai penentu nilai dan status hukum atas perbuatan seseorang, baik yang berhubungan dengan hal ibadah maupun interaksi antar sesama manusia.

Oleh karenanya, dapat disimpulkan bahwa setiap perbuatan yang tidak didasari oleh motivasi atau niat pada dasarnya perbuata tersebut bersifat spekulatif. Dan pada intinya, motivasi atau niat tersebut merupakan titik acu seseorang dalam setiap aktivitasnya. Sebab keduanya merupakan posisi yang sangat menentukan segala gerak tingkah dan kontruksi perbuatan manusia yang kemudian mempunyai konsekuensi yang bernilai baik maupun sebaliknya.

Sedangkan dalam kegiatan menabung yang didasari dengan niat atau motivasi awal yang baik, bukan tidak mungkin jika di kemudian hari akan mendatangkan keberkahan yang berlipat ganda. Sehingga teori motivasi menabung yang didasarkan dengan niat lillah, sudah selayaknya menjadi kebiasaan umat muslim khususnya mereka yang berstatus santri. ${ }^{17}$ Adapun beberapa motivasi atau niat tersebut antara lain:

a. Ingin hidup hemat;

b. Melatih diri untuk bersikap disiplin;

${ }^{17}$ Muhammad Ma'shum Zein, Aplikasi Teori Hukum Islam (Malang: Adulitera, 2019), 44.

164 Vol. 4, No. 2, September 2019 
c. Melatih diri untuk dapat memilah dan mendahulukan kebutuhan yang lebih penting;

d. Melatih diri untuk lebih bijak mengatur keuangan;

e. Sebagai simpanan jangka panjang;

f. Sebagai simpanan jika sewaktu-waktu membutuhkan uang;

g. Taat peraturan;

h. Agar uang tidak terbuang sia-sia, dsb.

\section{Akad-Akad dalam Tabungan}

Menabung merupakan tindakan yang sangat dianjurkan dalam Islam, karena dengan menabung adalah salah satu cara dimana seseorang telah mempersiapkan dirinya untuk perencanaan pelaksanaan masa yang akan datang dengan jalan lebih baik. Dan sehingga dengan adanya tabungan atau tindakan menabung manusia mempunyai simpanan jika suatu saat terjadi sesuatu kebutuhan yang di luar rencana. Dalam Al-Qur'an pun terdapat beberapa ayat yang secara tidak langsung memerintahkan kaum muslim untuk mempersiapkan guna menyambut hari esok yang lebih baik.

Bersiap-siap sebagaimana yang dimaksudkan adalah untuk antisipasi masa depan keturunan, baik secara rohani (iman/taqwa) maupun secara ekonomi. Hal tersebut harus dipikirkan dengan 
matang langkah-langkah perencanaannya. Dengan salah satu langkahnya yakni menabung seperti yang diterapkan di Pesantren. Diadakannya tabungan untuk santri selain bertujuan sebagai simpanan yang dapat digunakan ketika terjadi kebutuhan mendesak, juga sebagai sarana untuk memberikan pengajaran kedisiplinan.

Dalam tabungan yang menerapkan sistem syariah, terdapat akad yang melandasi transaksi tabungan tersebut. Adapun akad yang melandasi tabungan di Lembaga Pendidikan layaknya Pesatren yang paling tepat adalah akad wadiah. Hal ini sesuai dengan fatwa DSN yang menyatakan bahwa akad dalam tabungan merupakan akad wadi'ah karena merupakan akad investasi yang dilakukan dengan sukarela yang dilakukan untuk tujuan kepentingan simpanan demi terpenuhinya kebutuhan jangka panjang. ${ }^{18}$

\section{Definisi Akad Wadi'ah}

Wadiah dalam fiqh diartikan sebagai barang titipan atau memberikan harta untuk dijaga oleh penerimanya. Karenanya wadi'ah lebih dikenal sebagai sesuatu yang ditempatkan pada selain pemiliknya untuk dijaga. Sedangkan Al-Qur'an memaknai wadiah

18 Mufti Afif, "Tabungan: Implementasi Akad Wadi'ah atau Qardh", Jurnal Hukum Islam, 2 (Desember, 2014), 259.

166 Vol. 4, No. 2, September 2019 
adalah amanat bagi yang diberikan titipan (penerima titipan) dan wajib dikembalikan pada pemiliknya ketika diminta atau dibutuhkan. ${ }^{19}$

Wadi'ab adalah suatu transaksi menabung dimana mempunyai arti sebagai titipan murni oleh satu pihak ke pihak lainnya, baik oleh individu maupun badan hukum yang harus dikembalikan kapan saja jika si penyimpan menghendaki. ${ }^{20}$ Lembaga Perbankan mengartikan wadi'ah sebagai amanah yang berbentuk uang simpanan yang tidak berhak untuk disentuh oleh anggota lembaga (petugas/pegawai) dan hanya boleh dijaga kemurniannya agar tetap bebas dari unsur menyesatkan yang tidak sesuai dengan hukum Islam. ${ }^{21}$

\section{Sejarah Singkat Tabungan Santri Mandiri}

Tabungan santri di pondok pesantren Raudlatul Ulum merupakan program yang mulai diadakan sejak tahun 2014 lalu dengan nama "Tabungan Santri Mandiri” (TBSM) dengan status

\footnotetext{
${ }^{19}$ Dwi Suwiknyo, Kompilasi Tafsir Ayat-Ayat Ekonomi Islam (Yogyakarta: Pustaka Pelajar, 2010), 295.

20 Adiwarman A. Karim, Bank Islam, Analisis Fiqh dan Kenangan (Jakarta: PT. Raja Grafindo Persada, 2004), 23.

21 Ahmad Mustofa et.al., Reorientasi Ekonomi Syari'ah (Yogyakarta: UII Press, 2014), 189.
}

Iqtishodia : Jurnal Ekonomi Syariah 
lembaga otonom dan masih menggunakan pengurus pesantren sebagai operatornya. Didirikan tepatnya pada masa kepengurusan Gus. Abdur Rohim Sa’id. Berangkat dari ide-ide yang digagas untuk kemaslahatan santri agar terdidik dengan karekter hidup yang mandiri sesuai dengan motto pesantren yaitu "Berfikir Cerdas, Berakhlak Mulia, Kemandirian Hidup". Di samping upaya pengembangan berfikir dan berakhlak, menabung juga merupakan salah satu dari pendidikan karakter bermandiri dalam hidup. Alasan lain adalah maraknya kasus tunggakan santri yang tidak membayar syahriyah. Akan tetapi setelah diklarifikasi terhadap wali santri, ternyata rata-rata santri sudah dikirim oleh orang tua sekaligus dengan pembayaran syabriyah-nya.

Sejak tahun berdirinya hingga saat ini, program Tabungan Santri Mandiri hanya diwajibkan untuk kalangan santri atau internal pesantren. Bendahara pesantren merupakan pusat akhir pengelola dan penyimpanan uang tabungan santri. Dimana di bawahnya adalah pengurus daerah yang difungsikan untuk menjadi penanggung jawab tata kelola tabungan santri pada unit daerah masing-masing mulai dari pengurus daerah A, B, C dan D. Serta melakukan penyetoran 
terhadap bendahara pesantren selaku pengelola akhir setiap satu bulan satu kali. ${ }^{22}$

Secara garis besar manfaat adanya program tabungan santri sendiri dibagi menjadi dua antara lain: Manfaat bagi santri dan manfaat bagi pesantren. 1). Manfaat yang diperoleh santri adalah pendidikan karakter hidup hemat, ekonomis dan tidak boros. Kemudian membantu meringankan beban orang tua pada waktu liburan pesantren serta pemenuhan kebutuhan di masa mendatang. 2). Manfaat bagi pesantren antara lain membantu menunjang modal yang sewaktu-waktu membutuhkan nominal yang lebih sebagai peningkatan kapasitas perekonomian pesantren melalui unit usaha yang dimiliki, mencegah adanya tunggakan syahriyah santri dan membantu alumni, keluarga ndalem serta simpatisan pondok pesantren yang membutuhkan dana pinjaman dengan persyaratan yang sudah ditetapkan pesantren.

Akad yang digunakan dalam tabungan TBSM adalah akad alWadi'ah sebagaimana lembaga simpanan pada umumnya. Hanya saja, proses di awal santri menerima buku tabungan juga sekaligus bentuk persetujuannya untuk menerima semua kebijakan yang mengikat pada

22 Mursyid Hasan, Wawancara (Ganjaran, 18 Juni 2019). 
program TBSM tersebut termasuk pengelolaan uang tabungan demi kemaslahatan pesantren yang nantinya akan dirasakan mereka sendiri. Adapun dalam pencairannya, nominal tabungan santri sama sekali tidak berkurang ataupun bertambah. Tabungan santri mandiri menetapkan kebijakan dalam programnya antara lain: ${ }^{23}$

- Bersifat wajib bagi santri

- Minimal waktu menabung satu minggu satu kali

- Nominal minimal dalam satu minggu Rp. 2000,-

- Masa pencairan adalah satu tahun satu kali atau masa aktif pondok pesantren

- Ikhlas untuk dikelola demi kemaslahatan pesantren.

\section{Faktor-Faktor yang Melatarbelakangai Minat Menabung Santri}

Berdasarkan pengamatan yang dilakukan oleh peneliti, preferensi menabung santri dilatarbelakangai oleh beberapa hal berikut:

\section{a. Kelebihan Uang Saku}

23 Abdur Rohim Sa’id, Wawancara (Ganjaran, 2 Juli 2019).

170 Vol. 4, No. 2, September 2019 
Ketersediaan materi berpengaruh besar terhadap minat santri dalam menabung. Santri akan membuat pertimbangan antara menabung atau tidak manakala kebutuhan primernya sudah terpenuhi. Peluang santri dalam menyalurkan uangnya guna menabung akan mereka lakukan bilamana ketersediaan materi pasca pemenuhan kebutuhan primer. Namun, hal ini bukan merupakan patokan utama dimana ketersediaan materi merupakan motivator eksternal. Adapun penentunya adalah motivatsi internal yaitu kesadaran individual. "Terkadang uang kiriman yang saya dapat tidak bersisa pada kebutuhan dadakan sib pak. Ya terkadang juga ada sisa, dan dari sisa itulah saya sisibkan sebagian untuk menabung". ${ }^{24}$

\section{b. Kebutuhan Masa Mendatang}

Menginginkan masa liburan mereka memiliki uang saku tambahan merupakan motivator tersendiri bagi santri yang giat menyalurkan sebagian uangnya untuk melaksanakan program tabungan. Berangkat dari kesadaran, para santri ingin masa liburan mereka lebih mandiri dan tidak membebankan terhadap orang tua. Paling tidak sedikit meringankan dari pada harus menjadikan orang tua sebagai objek

24 Muhammad Jali, Wawancara (Ganjaran, 19 Mei 2019).

Iqtishodia : Jurnal Ekonomi Syariah 
permintaan. Mereka sadar bahwa di masa liburan yang akan datang, mereka akan membutuhkan lebih banyak uang untuk pemenuhan kebutuhan sebagaimana umumnya. Berangkat dari itu, maka menjadikan tabungan sebagai solusi kebutuhan di masa mendatang merupakan pilihan yang tepat. "Ya, karena di masa liburan mendatang kebutuban saya akan lebib banyak pak. Jika tanpa menabung, maka tidak akan ada sisa uang yang bisa kami pergunakan nantinya kecuali hanya meminta kepada orang tua". ${ }^{25}$

\section{c. Kepatuhan}

Kepatuhan terhadap undang-undang turut menjadi pengaruh tersendiri bagi preferensi menabung para santri. Tentu santri yang mengetahui bahwa dirinya dibebani tanggung jawab menjalankan peraturan atau kebijakan terhadap hal tertentu, akan dihadapkan pada dua kemungkinan. Pertama adalah kepatuhan, kemudian ketidak patuhan. Namun ketidak patuhan untuk menabung dalam konteks ini bukan dikarenakan peraturan yang mengikat seperti halnya diwajibkan. Namun karena aspek kesadaran sebagaimana akan dijelaskan pada poin pengaruh negatif di bawah.

${ }^{25}$ Fahmi Asikin, Wawancara (Ganjaran, 19 Mei 2019).

172 Vol. 4, No. 2, September 2019 


\section{d. Pengaruh Lingkungan Sekitar}

Bahwa perilaku lingkungan dapat berpengaruh besar terhadap turunnya tanggung jawab mereka untuk mengikuti program wajib Tabungan Santri Mandiri. Teman sekamar utamanya, dapat membujuk mereka untuk terpengaruh dalam memanage kebutuhan. Jika teman dalam ruang lingkup bergaul mereka tidak melakukan kewajiban menabung, akan membuat mereka turut melakukannya. Atau paling tidak sebagaimana yang dialami oleh beberapa santri aktif menabung bahwa pengaruh teman membuat nominal tabungan yang mereka setorkan semakin mengecil. "Sebab kebiasaan saya mengikuti teman pak. Bila mereka tidak menabung untuk lebih banyak jajan atau rokok. ya kami bisa ikutan. Atau kalaupun menabung ya dengan nominal yang sedikit' ${ }^{26}$

\section{e. Pelayanan}

Begitu pula dengan mereka yang aktif melakukan kegiatan wajib menabung. Bahwa motivasi menabung mereka dapat menurun secara perlahan sebab pelayanan kurang baik yang dilakukan oleh petugas yang berwajib menghimpun uang tabungan santri. Katakanlah

${ }^{26}$ Abdul Arif, Wawancara (Ganjaran, 18 Mei 2019). 
mereka adalah pengurus daerah. Ada beberapa faktor yang bisa dikatagorikan sebagai bentuk pelayanan yang kurang baik antara lain: Ketersediaan petugas di kantor mereka, kurangnya pengayoman dan pelaksanaan administrasi yang kurang baik turut mengakibatkan turunnya minat menabung santri. "Kadang juga ketika kita mau menabung, pengurus daerabnya belum tentu ada pak. Jadi kami tak jadi menabung dan membeli keperluan lain. Andai tabungan ditarik perkamar mungkin akan lebib banyak yang turut menabung pak. Sebab beban tanggung jawab akan lebih tinggi gitu". ${ }^{27}$

\section{f. Kesadaran}

Bagi beberapa santri yang tak pernah melakukan kegiatan wajib menabung selama kurun waktu kurang lebih dua tahun terakhir mengaku bahwa sebenarnya faktor mereka enggan untuk menabung adalah murni kurangnya kesadaran mereka sendiri. Terlepas dari faktor-faktor lain yang beberapa juga telah dialaminya. "Ya, sebenarnya dari kita sendiri pak yang kurang sadar..".

27 Abdur Rohman, Wawancara (Ganjaran, 17 Mei 2019).

${ }^{28}$ Huda, Wawancara (Ganjaran, 18 Mei 2019).

174 Vol. 4, No. 2, September 2019 


\section{Beberapa Hambatan Kebijakan Pesantren dalam Program Tabungan Santri Mandiri}

\section{a. Menganggap enteng}

Beberapa santri mengaku ketika diwawancarai bahwa sistem kebijakan wajib menabung dengan nominal minimal Rp. 2000,/Minggu lambat laun akan menimbulkan sifat menyepelekan. Hal ini dipandang dari sudut kecilnya nominal sehingga khususnya bagi santri yang malas menabung, nominal sesedikit itu akan membuat mereka mengundur-undur waktu sampai pada akhirnya uang mereka habis dengan sembrono. "Karena hanya dua ribu, mendorong saya untuk. selalu berniat menabung di akbir tempo waktu hingga uang saya habis dengan sendirinya pak". ${ }^{29}$

\section{b. Menyebabkan rasa malas}

Pengaruh berikut memiliki keterikatan yang kuat dengan poin pertama. Dimana kecilnya nominal ditambah seringnya masa minimal mereka harus menabungkan uang mereka menjadikan penyebab mereka menjadi malas. Terlepas dari kesadaran individual. "Sesering

${ }^{29}$ Wisnu Ardianto, Wawancara (Ganjaran, 18 Mei 2019). 
seminggu sekali kami harus setor uang sebanyak 2000 pak, jadinya malas. Anggapan kami dari pada hanya menabung 2000 ya lebih baik tidak. menabung". ${ }^{30}$

\section{c. Timbul sifat teledor}

Begitu pula dengan adanya kebijakan tersebut, santri yang telah memiliki rasa malas berkeyakinan bahwa mereka akan memenuhi tanggungan kewajiban menabungnya langsung pada akhir bulan dengan kelipatan nominal pada jumlah minggu dalam satu bulannya. Namun kenyataannya mereka hanya akan mendapati kekosongan uang di akhir bulan.

\section{d. Malu}

Rasa malu muncul akibat lingkungan. Bahwa teman sekamar yang memiliki kemampuan menabung dengan nominal Rp. 5000,- atau lebih dapat menyebabkan rasa gengsi bagi yang hanya mampu menabung Rp. 2000,- perminggunya.

\section{e. Kurangnya Soisialisasi}

30 Abd. Noval Hamdani, Wawancara (Ganjaran, 18 Maret 2019).

176 Vol. 4, No. 2, September 2019 
Berikut adalah faktor yang paling berperan sebagai penyurut tanggung jawab menabung para santri. Bahwa hasil observasi dan wawancara menyimpulkan bahwa rata-rata santri yang telah mencapai masa menyantri selama kurang lebih 2-3 tahun terakhir bahkan tidak mengetahui bahwa sistem tabungan santri itu adalah bersifat wajib. "Saya tahunya tabungan itu banya dianjurkan pak. Gak pernab tau kalau termyata wajib". ${ }^{31}$ Dan juga tidak sama sekali mengetahui bahwa kebijakan mereka dalam menabung adalah setidaknya dalam satu minggu minimal Rp. 2000,-. Terlepas dari segala kebijakan yang tidak mereka ketahui adalah bahwa ketegasan yang kurang optimal dalam penjalanan program Tabungan Santri Mandiri juga merupakan faktor surutnya para santri untuk menabung. "Mengenai minimal Rp. 2000,/ Minggunya itu saya kurang memahami betulpak sebab dari awal saya mondok memang gake pernah tau. Selama ini memang tidak ada ketegasan atau sosialisasi masalab tabungan. Hanya seakan dianjurkan saja". 32

\section{Penutup}

${ }^{31}$ Huda, Wawancara (Ganjaran, 18 Mei 2019).

${ }^{32}$ Fahmi Asikin, Wawancara (Ganjaran, 19 Mei 2019).

Iqtishodia : Jurnal Ekonomi Syariah 
Berdasarkan rumusan masalah dan hasil pembahasan penelitian, dapat disimpulkan bahwa faktor-faktor yang melatarbelakangai preferensi menabung santri yaitu faktor positif yang merupakan hal-hal yang dapat menjadi stimulus bagi minat dan motivasi mereka untuk menjalankan tanggung jawab wajib menabung. Faktor ini meliputi: keberadaan sisa uang jajan, investasi masadepan, ketaatan terhadap peraturan hingga pengaruh lingkungan sekitar. Kedua, hal-hal yang dapat menjadi penghambat bagi minat dan motivasi mereka untuk enggan menjalankan tanggung jawab wajib menabung meliputi kurangnya sosialisasi, pelayanan yang kurang baik, keterbatasan ekonomi dan lainnya.

\section{Daftar Pustaka}

Muhamad. 2016. Manajemen Keuangan Syari'ah, Cet. II. Yogyakarta: UPP STIM YKPN.

Fatoni, Siti Nur. 2014. Pengantar Ilmu Ekonomi. Cet. I. Bandung: Pustaka Setia.

Undang-Undang Republik Indonesia Nomor 10 Tahun 1998 Tentang Perbankan.

Syuhud, Fatih. 2008. Santri, Pesantren dan Tantangan Pendidikan Islam, Cet. II. Karangsuko: Pustaka ALKHOIROT.

178 Vol. 4, No. 2, September 2019 
Hakim, Rahmad. "Islamisasi Ekonomi Madz̧hab Mainstream: Tinjauan, Model dan Implikasi”, Iqtishodia: Jurnal Ekonomi Syari'ah, Vol. 1, No.1, (Maret, 2016), 81-82.

Partanto, Pius A. 2001. Kamus Ilmiah Populer. Surabaya: Arkola.

Haris, Muhammad. 2015. "Analisis Faktor-Faktor yang Mempengarubi Preferensi Nasabah Terbadap Bank Syariah di DKI Jakarta", Skripsi. Bogor: Institut Pertanian Bogor.

Mappiare, Andi. 1997. Psikologi Remaja. Surabaya: Usaha Nasional. Anshori, Abdul Ghofur. 2009. Perbankan Syariah di Indonesia. Yogyakarta: Gadjah Mada University Press.

Al Arif, M. Nur Rianto. 2012. Dasar-Dasar Ekonomi Islam, Cet. II. Bandung: Alfabeta.

Boeree, C. George. 2014. Psikologi Sosial. Jogjakarta: Primashopie.

Wahyu Utami, et.al., "Analisis Pengarub Religinitas, Kelompok Referensi, dan Motivasi Terbadap Keputusan Menabung di Bank Syariab", Jurnal Wawasan Manajemen, Vol. 3, 1 (Februari, 2015).

Zein, Muhammad Ma'shum. 2019. Aplikasi Teori Hukum Islam. Malang: Adulitera.

Afif, Mufti 'Tabungan: Implementasi Akad W adi'ah atan Qardh", Jurnal Hukum Islam, 2. Desember, 2014. 
Suwiknyo, Dwi. 2010. Kompilasi Tafsir Ayat-Ayat Ekonomi Islam.

Yogyakarta: Pustaka Pelajar.

Karim, Adiwarman A. 2004. Bank Islam, Analisis Fiqh dan Keuangan.

Jakarta: PT. Raja Grafindo Persada.

Ahmad Mustofa et.al., 2014. Reorientasi Ekonomi Syariah. Yogyakarta: UII Press.

Mursyid Hasan, Wawancara. Ganjaran, 18 Juni 2019.

Abdur Rohim Sa’id, Wawancara. Ganjaran, 2 Juli 2019.

Muhammad Jali, Wawancara. Ganjaran, 19 Mei 2019.

Fahmi Asikin, Wawancara. Ganjaran, 19 Mei 2019.

Abdul Arif, Wawancara. Ganjaran, 18 Mei 2019.

Abdur Rohman, Wawancara. Ganjaran, 17 Mei 2019.

Huda, Wawancara. Ganjaran, 18 Mei 2019.

Wisnu Ardianto, Wawancara. Ganjaran, 18 Mei 2019.

Abd. Noval Hamdani, Wawancara. Ganjaran, 18 Maret 2019.

Huda, Wawancara. Ganjaran, 18 Mei 2019.

Fahmi Asikin, Wawancara. Ganjaran, 19 Mei 2019. 